\section{CRF and the nucleus incertus: a node for integration of stress signals}

\author{
Leigh C. Walker and Andrew J. Lawrence
}

We recently read with interest the timely and scholarly Review by Henckens et al. (Regionspecific roles of the corticotropin-releasing factor-urocortin system in stress. Nat. Rev. Neurosci. 17, 636-651 (2016) $)^{1}$ on the regionspecific actions of the corticotropin-releasing factor (CRF)-urocortin system in stress neurobiology. However, we note an inadvertent but important omission: a role for CRF signalling in the nucleus incertus.

The nucleus incertus (NI; also known as the 'nucleus O') is located in the pons, below the fourth ventricle ${ }^{2}$. This highly conserved structure consists mainly of GABAergic projection neurons, innervates many forebrain regions ${ }^{3}$ and has been implicated in various behaviours including arousal and responses to stress ${ }^{2,4}$. NI neurons express CRF receptor type 1 (CRFR1) protein and mRNA in abundance ${ }^{5}$, and electrophysiological characterization in vitro and in vivo has revealed that CRF depolarizes NI cells via postsynaptic CRFR1 in a long-lasting and non-desensitizing manner ${ }^{6}$. Substantial evidence confirms the importance of CRF signalling in the NI in relation to various stress-related disorders, such as anxiety (reviewed in REFS 2,7).

Central infusion of CRF, or exposure to neurogenic stressors (including behavioural or pharmacological stressors), directly or indirectly activates NI neurons ${ }^{4}$. Electrolytic lesioning of the $\mathrm{NI}^{8}$ and selective ablation of CRFR1-positive NI neurons using CRFsaporin $^{9}$ cause deficits in fear extinction without impairing initial conditioning. Moreover, selective pharmacogenetic activation of NI neurons causes enhanced arousal, locomotion, vigilance and active responding behaviours during fear conditioning ${ }^{10}$. CRF infusion into, or electrical stimulation of, the NI impairs long-term potentiation (LTP) of hippocampal-medial prefrontal cortical synapses ${ }^{11}$, whereas intra-NI infusion of the CRFR1 antagonist antalarmin reversed stress-induced suppression of LTP in this pathway ${ }^{12}$. Intra-NI infusion of the CRFR1 antagonist CP-376395, but not the CRFR2 antagonist astressin 2B, considerably reduced the reinstatement of alcohol seeking in rats that was induced by administration of the pharmacological stressor yohimbine $\mathrm{e}^{13}$ - an effect that is probably mediated by CRFR1 activation of relaxin-3-positive NI neurons $s^{6,14}$. The NI is therefore a stressresponsive nucleus and, through CRFR1, contributes to memory and learning, stressinduced reward seeking, impairments in neuronal plasticity, and arousal behaviours ${ }^{9-13}$.

The lateral preoptic area sends CRFcontaining projections to the $\mathrm{NI}^{6}$; however, other CRF-positive regions that do the same require further clarification. Given the close proximity of the NI to the fourth ventricle, CRF may activate NI neurons through volume transmission from the cerebrospinal fluid $^{15}$. Furthermore, it has recently been discovered that $C r f$ mRNA and CRF protein are expressed in the rodent $\mathrm{NI}^{13}$, therefore, $\mathrm{CRF}$ release intrinsic to the NI cannot be ruled out, although the phenotype and function of these CRF-positive cells require elucidation.

In conclusion, there is substantial evidence that CRF signalling in the NI has relevant neurophysiological implications. Research into neuropsychiatric disorders should also investigate pathways and regions such as the NI that integrate relevant behavioural repertoires. This may lead to a broader understanding of brain networks acting in dysregulated states and could assist in the identification of potential therapeutic targets in anxiety, substance abuse and other neuropsychiatric disorders.

Leigh C. Walker and Andrew J. Lawrence are at the Florey Institute of Neuroscience and Mental Health, University of Melbourne, Parkville, Victoria 3052, Australia.

Correspondence to A.J.L. Andrew.Lawrence@florey.edu.au doi: $10.1038 / \mathrm{nrn} .2016 .158$ Published online 24 Nov 2016
1. Henckens, M. J., Deussing, J. M. \& Chen, A. Regionspecific roles of the corticotropin-releasing factorurocortin system in stress. Nat. Rev. Neurosci. 17, 636-651 (2016).

2. Ma, S. \& Gundlach, A. L. Ascending control of arousal and motivation: role of nucleus incertus and its peptide neuromodulators in behavioural responses to stress. J. Neuroendocrinol. 27. 457-467 (2015).

3. Olucha-Bordonau, F. E. et al. Cytoarchitecture and efferent projections of the nucleus incertus of the rat. J. Comp. Neurol. 464, 62-97 (2003).

4. Ryan, P. J., Ma, S., Olucha-Bordonau, F. E. \& Gundlach, A. L. Nucleus incertus - an emerging modulatory role in arousal, stress and memory. Neurosci. Biobehav. Rev. 35, 1326-1341 (2011).

5. Potter, E. et al. Distribution of corticotropin-releasing factor receptor mRNA expression in the rat brain and pituitary. Proc. Natl Acad. Sci. USA 91, 8777-8781 (1994).

6. Ma, S., Blasiak, A., Olucha-Bordonau, F. E., Verberne, A. J. \& Gundlach, A. L. Heterogeneous responses of nucleus incertus neurons to corticotrophin-releasing factor and coherent activity with hippocampal theta rhythm in the rat. J. Physiol. 591, 3981-4001 (2013)

7. Kumar, J. R. \& Rajkumar, R. Relaxin' the brain: a case for targeting the nucleus incertus network and relaxin-3/RXFP3 system in neuropsychiatric disorders. Br. J. Pharmacol. http://dx.doi.org/10.1111/ bph.13564 (2016)

8. Pereira, C. W. et al. Electrolytic lesion of the nucleus incertus retards extinction of auditory conditioned fear. Behav. Brain Res. 247, 201-210 (2013).

9. Lee, L. C., Rajkumar, R. \& Dawe, G. S. Selective lesioning of nucleus incertus with corticotropin releasing factor-saporin conjugate. Brain Res. 1543, 179-190 (2014).

10. Ma, S. et al. Nucleus incertus promotes cortical desynchronization and behavioral arousal. Brain Struct. Funct. http://dx. doi.org/10.1007/s00429016-1230-0 (2016).

11. Farooq, U. et al. Corticotropin-releasing factor infusion into nucleus incertus suppresses medial prefrontal cortical activity and hippocampo-medial prefrontal cortical long-term potentiation. Eur J. Neurosci. 38, 2516-2525 (2013)

12. Rajkumar, R., Wu, Y., Farooq, U., Tan, W. H. \& Dawe, G. S. Stress activates the nucleus incertus and modulates plasticity in the hippocampo-medial prefrontal cortical pathway. Brain Res. Bull. 120, 83-89 (2016).

13. Walker, L. C. et al. Nucleus incertus corticotrophinreleasing factor 1 receptor signalling regulates alcohol seeking in rats. Addict. Biol. http://dx.doi. org/10.1111/adb.12426 (2016).

14. Ryan, P. J. et al. Relaxin-3/RXFP3 system regulates alcohol-seeking. Proc. Natl Acad. Sci. USA 110 20789-20794 (2013)

15. Bittencourt, J. C. \& Sawchenko, P. E. Do centrally administered neuropeptides access cognate receptors? An analysis in the central corticotropinreleasing factor system. J. Neurosci. $\mathbf{2 0}$, 1142-1156 (2000).

\section{Acknowledgements}

A.J.L. is an Australian National Health and Medical Research Council (NHMRC) principal fellow (1020737). L.C.W. is supported by an Australian postgraduate scholarship. The authors also acknowledge the Victorian Government's Operational Infrastructure Support Program.

\section{Competing interests statement}

The authors declare no competing interests. 